\title{
Do Catch-and-Release Guidelines from State and Provincial Fisheries Agencies in North America Conform to Scientifically Based Best Practices?
}

\author{
Christine Pelletier $\cdot$ Kyle C. Hanson • \\ Steven J. Cooke
}

Received: 18 May 2006/ Accepted: 28 October 2006

(C) Springer Science+Business Media, LLC 2007

\begin{abstract}
Many recreational anglers practice catchand-release angling, where fish are returned to the water with the presumption that they will survive. However, not all fish survive, and those that do often experience sublethal consequences including injury and stress. There is compelling scientific evidence that angler behavior and gear choice can affect the success of catch-and-release as a management and conservation strategy. Because anglers often look to government natural resource agencies for guidance on how to handle and release fish properly, there is a need to assess whether their outreach materials are readily accessible and provide the necessary and correct information on the subject. Therefore, on-line catchand-release guidelines developed by state and provincial natural resource agencies across North America were evaluated to determine whether their guidelines were consistent with the best available scientific information. This analysis revealed that there was immense variation in the depth and breadth of coverage among jurisdictions. Agency guidelines contradicted one another in several areas including air exposure, angling in deep water, venting trapped gases, and resuscitation. In many cases, the guidelines failed to provide sufficient direction to actually be of use to anglers or provide direction consistent with contem-
\end{abstract}

C. Pelletier · S. J. Cooke ( $\square)$

Institute of Environmental Science, Carleton University, 1125 Colonel By Drive, Ottawa, Ontario, Canada, K1S 5B6

e-mail: Steven_Cooke@carleton.ca

\section{K. C. Hanson}

Fish Ecology and Conservation Physiology Laboratory, Ottawa Carleton Institute of Biology, Carleton University, 1125 Colonel By Drive, Ottawa, Ontario, Canada, K1S 5B6 porary scientific literature. This analysis will assist with developing outreach materials that promote sustainable recreational fisheries and in maintaining the welfare status of individual fish.

Keywords Fisheries management - Recreational fishing $\cdot$ Catch-and-release $\cdot$ Education $\cdot$ Outreach

Recreational fishing is a popular activity around the world (Arlinghaus et al. 2002; Cowx 2002; Cooke and Cowx 2004; 2006). In North America, it is estimated that only $12 \%$ of the adult population has never engaged in recreational fishing activity (NOAA 2001). Many anglers practice catch-and-release, where fish are captured and released immediately, or after a brief retention period. Catch-and-release can be mandated through use of regulations, but is most commonly a voluntary activity based on either a consumptive motivation to recapture released fish or a nonconsumptive motivation to preserve the fish in the stock for their own sake. Many anglers now practice selective harvest where some fish are released and some fish are harvested. From a fisheries management standpoint, it is critical that fish that are subject to catch-and-release survive and experience negligible sublethal effects (Wydoski 1977; Cooke et al. 2002). In jurisdictions where stocking is not a common management strategy, reducing fishing-induced mortality is particularly crucial. Many of the current management strategies (e.g., slot limits, maximum size limits) used depend upon the regulated release of select individuals with the notion that fish will be able to be captured multiple times (Quinn 1996). Unfortunately, mortality rates vary widely and have been shown to exceed $75 \%$ in some 
species (reviews in Muoneke and Childress 1994; Bartholomew and Bohnsack 2005). Sometimes, mortality occurs immediately as a result of lethal injury. However, there is a growing body of evidence that suggests that there is also latent mortality (hours to days) that tends to arise from the additive effects of a number of stressors, injuries, and disease (Cooke et al. 2002).

Although there are many factors that can contribute to catch-and-release mortality, there is evidence that by identifying these factors it is often possible to reduce stress, injury, and mortality. Scientific studies have revealed that anglers can make choices in gear type or angling practices to improve the outcome of the catch-and-release angling event for the fish (Cooke and Suski 2005). In fact, there are now many examples of how adoption of specialized angling gear (e.g., circle hooks, Cooke and Suski 2004) and better handling practices (e.g., Wilde et al. 2000) can have dramatic reductions in catch-and-release mortality. In addition, fish welfare has recently been regarded as an important topic, and thus there is a need to ensure that anglers contribute to maintaining the welfare status of angled fish (Cooke and Sneddon in press). However, anglers rarely consult scientific literature and may thus be unaware of contemporary research on this topic. Instead, anglers rely on government natural resource agencies (usually at the state or provincial level) to summarize such scientific studies and to provide guidance on how to minimize catch-and-release mortality. The presumption is that these agencies would provide credible information that is based on scientific study. However, there has never been a formal assessment of whether the outreach materials that governments provide are easily accessible, factually correct, and comprehensive.

The goal of the current study was to examine existing natural resource agency guidelines and to assess both their consistency and their conformity with the best scientific information on catch-and-release practices. To achieve this goal, the latest scientific literature on catch-and-release was reviewed to establish what the "best practices" were for a given issue. A database was created of on-line catch-and-release guidelines developed by every state and provincial natural resource agency across North America. Each agency's catch-and-release guidelines were then assessed to determine whether or not they were consistent with the best available scientific literature and whether or not they were easily accessible to the general public. With this information, specific topical areas were identified where there was conflicting information (either among agencies, or between agency guidelines and published scientific data). Finally, recommended approaches were made for ensuring that the best scientific information on catch-and-release angling is disseminated to anglers.

\section{Methods}

Locating Catch-and-Release Guidelines on Natural Resource Agency Websites

A database was created of every state and provincial natural resource agency across North America including Canadian territories and noncontinental United States (i.e., Hawaii, Alaska). Although there are also Federal agencies (e.g., Parks Canada, United States Fish and Wildlife Service, National Oceanic and Atmospheric Administration, United States Parks Service, Sea Grant, and Fisheries and Oceans Canada) that have jurisdiction over some fisheries (mostly coastal and marine), it was presumed that most anglers required to purchase state or provincial fishing licenses would initially look for information at the state or provincial level. The on-line catch-and-release guidelines developed by each agency were then located. The focus was on Web-based (WWW) sources because this is generally the easiest way for the public to access information published by the government. Several years ago, most natural resource agencies produced paper copies of regulation books (many contained catch-and-release guidelines) and anglers could have picked up copies of such information at the nearest natural resource agency (or their agent, e.g., sporting goods store). However, with people now having Internet access at their home, workplace, or local library, information is readily accessible electronically. Government agencies have increasingly been publishing information on-line rather than in print because it is more cost-effective, less time consuming, and requires less paper. In addition, electronic publications can be updated frequently without the expense of reprinting. For these reasons, research was focused solely on Web-based catch-and-release guidelines.

The first search was on the agency's Fish and Wildlife homepage (or a version thereof) for a link to catch-and-release angling guidelines. When there was no link directly off the main page, the Fishing link or "Fisheries Section/Division" was followed and the search continued for catch-and-release materials using logic that would be used by anglers searching for such information. Often, searching required using the agency's search engine, Google, or searching within 
the agency's 2005/2006 fishing regulations book. In some cases, agency headquarters were telephoned for assistance in locating the guidelines. Efforts were focused on trying to locate the primary set of "generic" guidelines that provided anglers with direction on how to handle and release fish. Some natural resource agencies had species-specific, location-specific, or gear-specific guidelines, but these tended to be more detailed and would likely only be accessed by specialized anglers and were therefore excluded from this analysis. In instances where there were multiple versions of guidelines available on a Web site, the one that was most accessible was selected. All analyses were conducted between December 2005 and January 2006.

\section{Establishing Specific Questions for the Agencies Regarding Catch-and-Release}

Questions regarding catch-and-release were developed to determine whether or not agency guidelines conformed to scientifically based best practices. Initially, 46 questions were developed covering every stage of a catch-and-release event when an angler can choose to adopt "best practices" in order to increase survivorship or decrease sublethal effects. In this context, "best practice" was based on several recent syntheses on advances in catch-and-release science (e.g., Muoneke and Childress 1994; Bartholomew and Bohnsack 2005; Cooke and Suski 2005; Cooke and Sneddon in press) or contemporary empirical studies. Although the literature often lacked consistency, the interpretation of best practice was based on what was found by the majority of peer-reviewed studies and tended to be more cautious when there were competing opinions (Cooke and Suski 2005). Consultation of the literature was a critical first step because it revealed specific inconsistencies that could also be reflected in the Web-based guidelines. After completing the extraction of findings from each Web site, the 46 initial questions were "collapsed" into more general questions where appropriate to enable appropriate comparison. Criteria were also developed for evaluating the accessibility of the catch-and-release guidelines. This was done by quantifying the minimum number of "mouse" clicks required to navigate from the agency homepage to the catch-andrelease guidelines. The number of words on each Web site was counted as a rough measurement of the relative breadth and depth of information available.

\section{Results and Discussion}

\section{Breadth and Depth of Coverage}

This study compared the Internet-based catch-andrelease guidelines for 49 of 62 North American natural resource agencies: 10 Canadian and 39 American (Table 1). Online guidelines for the remaining 12 agencies could not be found (Table 1). Interestingly, one explanation for not having an electronic source of this information was that catch-and-release cannot be explained in writing; rather, it must be demonstrated in the field (hence no online source of information in Nevada; telephone interview with a representative from the Nevada Department of Wildlife in February).

There was immense variation in the accessibility of catch-and-release guidelines as assessed by quantifying the number of mouse "clicks" required to locate guidelines from the primary agency Web site homepage. The number of "clicks" required ranged from two to seven (Table 1 ; mean $\pm \mathrm{SD}, 2.8 \pm 0.96$ ). Four agency guidelines could only be found using an Internet search engine (either intra-agency or Google) because links to their information were not intuitively obvious. Eleven agency guidelines were accessed via a link directly from the primary "fisheries" Web page. The remaining were either located within the "2006 Fishing Regulations Guidebook" or in a separate document under the heading "Publications." There were no guidelines available directly from a primary natural resource agency homepage.

Word count for information presented in the guidelines varied extensively, from a low of 25 (New Brunswick) to a high of 1744 (Maryland) (Table 1; mean \pm SD, $378 \pm 360$ words). Aside from the actual content, there was no consistent format for the guidelines. Some were written in point form, others in detailed paragraphs; some contained illustrations, others only text; and, some were in Adobe PDF format, others in html. All guidelines were accessed free of charge and without need for passwords or special $\log$-in.

Do Catch-and-Release Guidelines from Natural Resource Agencies Conform with Best Available Science?

Data from the assessment are presented under general topical headings relevant to best practice for catchand-release angling. 
Table 1 Accessibility $^{\text {a }}$ of online catch-and-release guidelines for 13 Canadian provinces/territories and the 50 American states

\begin{tabular}{|c|c|c|c|c|}
\hline Province/state & $\begin{array}{l}\text { Online } \\
\text { guidelines } \\
(\mathrm{Y} \text { or } \mathrm{N})\end{array}$ & $\begin{array}{l}\text { Search } \\
\text { engine } \\
\text { required }\end{array}$ & $\begin{array}{l}\text { Number } \\
\text { of } \\
\text { clicks }\end{array}$ & $\begin{array}{l}\text { Word } \\
\text { count }\end{array}$ \\
\hline \multicolumn{5}{|l|}{ Canada } \\
\hline Alberta & $\mathrm{Y}$ & $\mathrm{N}$ & 4 & 434 \\
\hline British Columbia & $\mathrm{Y}$ & $\mathrm{N}$ & 2 & 340 \\
\hline Manitoba & $\mathrm{Y}$ & $\mathrm{N}$ & 3 & 213 \\
\hline New Brunswick & $\mathrm{Y}$ & $\mathrm{N}$ & 3 & 25 \\
\hline $\begin{array}{l}\text { Newfoundland/ } \\
\text { Labrador }\end{array}$ & $\mathrm{N}$ & & & \\
\hline Northwest Territory & $\mathrm{Y}$ & $\mathrm{N}$ & 2 & 66 \\
\hline Nova Scotia & $\mathrm{Y}$ & $\mathrm{N}$ & 3 & 327 \\
\hline Nunavut Territory & $\mathrm{N}$ & & & \\
\hline Ontario & $\mathrm{Y}$ & $\mathrm{N}$ & 3 & 1339 \\
\hline Prince Edward Island & $\mathrm{Y}$ & $\mathrm{N}$ & 3 & 127 \\
\hline Quebec & $\mathrm{Y}$ & $\mathrm{N}$ & 2 & 166 \\
\hline Saskatchewan & $\mathrm{Y}$ & $\mathrm{N}$ & 2 & 834 \\
\hline Yukon Territory & $\mathrm{Y}$ & $\mathrm{N}$ & 3 & 857 \\
\hline \multicolumn{5}{|l|}{ United States } \\
\hline Alabama & $\mathrm{Y}$ & $\mathrm{Y}$ & 5 & 594 \\
\hline Alaska & $\mathrm{Y}$ & $\mathrm{Y}$ & 2 & 487 \\
\hline Arizona & $\mathrm{Y}$ & $\mathrm{N}$ & 2 & 235 \\
\hline Arkansas & $\mathrm{Y}$ & $\mathrm{N}$ & 2 & 164 \\
\hline California & $\mathrm{Y}$ & $\mathrm{Y}$ & 4 & 1361 \\
\hline Colorado & $\mathrm{Y}$ & $\mathrm{N}$ & 3 & 113 \\
\hline Connecticut & $\mathrm{N}$ & & & \\
\hline Delaware & $\mathrm{Y}$ & $\mathrm{N}$ & 3 & \\
\hline Florida & $\mathrm{Y}$ & $\mathrm{N}$ & 7 & 683 \\
\hline Georgia & $\mathrm{Y}$ & $\mathrm{N}$ & 3 & 135 \\
\hline Hawaii & $\mathrm{N}$ & & & \\
\hline Idaho & $\mathrm{Y}$ & $\mathrm{N}$ & 4 & 195 \\
\hline Illinois & $\mathrm{N}$ & & & \\
\hline Indiana & $\mathrm{Y}$ & $\mathrm{N}$ & 2 & 178 \\
\hline Iowa & $\mathrm{N}$ & & & \\
\hline Kansas & $\mathrm{N}$ & & & \\
\hline Kentucky & $\mathrm{Y}$ & $\mathrm{N}$ & 3 & 236 \\
\hline Louisiana & $\mathrm{Y}$ & $\mathrm{N}$ & 2 & 271 \\
\hline Massachusetts & $\mathrm{Y}$ & $\mathrm{N}$ & 2 & 357 \\
\hline Maine & $\mathrm{Y}$ & $\mathrm{N}$ & 2 & 354 \\
\hline Maryland & $\mathrm{Y}$ & $\mathrm{Y}$ & 3 & 1744 \\
\hline Michigan & $\mathrm{Y}$ & $\mathrm{Y}$ & 3 & 189 \\
\hline Minnesota & $\mathrm{Y}$ & $\mathrm{Y}$ & 4 & 136 \\
\hline Missouri & $\mathrm{Y}$ & $\mathrm{N}$ & & 174 \\
\hline Mississippi & $\mathrm{N}$ & & & \\
\hline Montana & $\mathrm{Y}$ & $\mathrm{N}$ & 3 & 242 \\
\hline Nebraska & $\mathrm{Y}$ & $\mathrm{N}$ & 3 & 157 \\
\hline Nevada & $\mathrm{N}$ & & & \\
\hline New Hampshire & $\mathrm{Y}$ & $\mathrm{N}$ & 3 & 366 \\
\hline New Jersey & $\mathrm{N}$ & & & \\
\hline New Mexico & $\mathrm{Y}$ & $\mathrm{N}$ & 2 & 47 \\
\hline New York & $\mathrm{Y}$ & $\mathrm{N}$ & 4 & 271 \\
\hline North Carolina & $\mathrm{Y}$ & $\mathrm{Y}$ & 3 & 379 \\
\hline North Dakota & $\mathrm{Y}$ & $\mathrm{Y}$ & 2 & 65 \\
\hline Ohio & $\mathrm{Y}$ & $\mathrm{N}$ & 2 & 117 \\
\hline Oklahoma & $\mathrm{Y}$ & $\mathrm{N}$ & 2 & 229 \\
\hline Oregon & $\mathrm{Y}$ & $\mathrm{N}$ & 3 & 319 \\
\hline Pennsylvania & $\mathrm{Y}$ & $\mathrm{N}$ & 3 & 285 \\
\hline Rhode Island & $\mathrm{N}$ & & & \\
\hline South Carolina & $\mathrm{Y}$ & $\mathrm{N}$ & 3 & 512 \\
\hline South Dakota & $\mathrm{Y}$ & $\mathrm{N}$ & 2 & 1127 \\
\hline Tennessee & $\mathrm{Y}$ & $\mathrm{N}$ & 2 & 375 \\
\hline
\end{tabular}

Table 1 Continued

\begin{tabular}{lllll}
\hline & $\begin{array}{l}\text { Online } \\
\text { guidelines } \\
\text { (Y or N) }\end{array}$ & $\begin{array}{l}\text { Search } \\
\text { engine } \\
\text { required }\end{array}$ & $\begin{array}{l}\text { Number } \\
\text { of } \\
\text { clicks }\end{array}$ & $\begin{array}{l}\text { Word } \\
\text { count }\end{array}$ \\
\hline Texas & $\mathrm{Y}$ & $\mathrm{N}$ & 2 & 499 \\
Utah & $\mathrm{Y}$ & $\mathrm{N}$ & 2 & 437 \\
Virginia & $\mathrm{Y}$ & $\mathrm{N}$ & 3 & 306 \\
Vermont & $\mathrm{Y}$ & $\mathrm{N}$ & 3 & 455 \\
Washington & $\mathrm{N}$ & & & \\
Wisconsin & $\mathrm{Y}$ & $\mathrm{N}$ & 4 & 73 \\
West Virginia & $\mathrm{Y}$ & $\mathrm{N}$ & 2 & 115 \\
Wyoming & $\mathrm{Y}$ & $\mathrm{N}$ & 3 & 195 \\
\hline
\end{tabular}

${ }^{a}$ Accessibility was determined by whether or not each jurisdiction had online guidelines, whether or not a user would be required to use a search engine to find the guidelines, and then by the number of "mouse" clicks to find the guidelines on the main natural resource agency's Web site. Lastly, as a measure of the amount of information provided, the word count for the catch and release guidelines was generated

\section{Hook and Bait Type}

\section{Barbed vs. barbless hooks}

Barbless hooks were recommended by 34 (or 69\%) agencies as an alternative to barbed hooks. Perhaps the remaining 15 agencies have not suggested that barbless hooks are beneficial relative to barbed hooks because literature accounts are contradictory (e.g., Taylor and White 1992; Schill and Scarpella 1997; Turek and Brett 1997). However, there is compelling evidence that barbless hooks are easier to remove than barbed hooks (Diggles and Ernst 1997; Schaeffer and Hoffman 2002; Cooke et al. 2001; Meka 2004). Ease of removal results in reduced handling time and tissue damage, thereby decreasing associated mortality (Cooke et al. 2001).

Although barbless hooks are generally less harmful to fish, they may not be the hook of choice for all anglers because barbed hooks may in fact land more fish (Schaeffer and Hoffman 2002). Perhaps the perception that catch rates will suffer has discouraged the adoption of barbless hooks in place of barbed hooks, and this issue is viewed erroneously as just a social one (Schill and Scarpella 1997). It is important that agencies inform anglers of the link between hook type and injury or mortality. This is particularly relevant because tissue damage can be reduced with use of barbless hooks, which is consistent with maintaining welfare status.

\section{Circle hooks vs. "J" style hooks}

Five of 49 agencies recommended using circle hooks in place of the conventional "J" style hooks. With 
circle hooks, the point of the hook is generally oriented to be perpendicular to the shank, whereas Jstyle hooks have the point parallel to the shank (Cooke and Suski 2004). Having conducted research on the use of both hook styles, the Massachusetts Division of Marine Fisheries (MDMF) (2005) strongly encourages the use of circle hooks when using natural bait. The MDMF found that circle hooks showed a significant reduction in the rate of potential lethal wounding, and subsequent mortality. This specific suite of studies is consistent with a broader metaanalysis conducted by Cooke and Suski (2004). They reviewed existing research on circle hooks from more than 40 studies and found that overall mortality rates were considerably lower ( $\sim 50 \%$ lower overall) for circle hooks than J-style hooks. This is attributed to circle hooks having a demonstrable positive impact on anatomical hooking location (i.e., less injurious tissues, more shallow hooking depths; Cooke and Suski 2004). However, it is important to note that there is variation among species; evidence suggests that, in bluegill, the incidence of eye injuries may be greater for circle hooks (Cooke et al. 2003). According to Cooke and Suski (2004), anglers must modify their angling technique for circle hooks to function effectively. Specifically, a circle hook should not be set when a fish hits. One manufacturer, Eagle Claw, stresses this message with a label on its circle hook packages: "On the take, do NOT set the hook; just reel fish in." Because circle hooks are used almost exclusively with live bait, the premise is that as the fish tries to consume the baited circle hook, the fish moves away, or a gentle pressure from the angler pulls the hook to the side of the mouth, thus hooking the fish superficially rather than in the gut (Johannes 1981). If the hook is set with the normal vigor used for conventional hooks, the hook will either not capture the fish at all, or is more likely to hook the fish in locations that are injurious (Cooke and Suski 2004). The states of South Carolina, Delaware, Maryland, and California all recommended the use of circle hooks when using natural baits; however, they did not include information on proper technique. It is recommended that agencies promoting the adoption of circle hooks provide appropriate background information, scientific data, and detailed instructions for their use. It is also important for agencies to provide explicit direction as to other circle hook characteristics. For example, a study of billfish revealed that use of off-set circle hooks had no conservation benefit relative to J-style hooks (Prince et al. 2002). Thus, only in-line circle hooks are recommended for use on billfish (Prince et al. 2002).
Single vs. treble hooks

Although several studies have reported that single hooks tend to produce less injury than treble hooks (Gjernes et al. 1993; DuBois et al. 1994; Muoneke and Childress 1994; Schisler and Bergersen 1996), agency Web sites provided little information on the subject. Only 4 of 49 agencies recommended using single hooks in place of treble hooks. Of these, three agencies also specify that artificial lures should be used as an alternative to natural bait. The single hook and artificial lure combination has been the focus of several studies. Muoneke and Childress (1994) and Schisler and Bergersen (1996) report that single-hook flies tend to produce less injury (and mortality) than do organic baits (e.g., worms, baitfish, dough) or lures with treble hooks. The Ontario Ministry of Natural Resources (OMNR) and the Utah Division of Wildlife Resources explained that replacing treble hooks with single hooks will make live release easier. Because air exposure tends to occur when anglers remove hooks, these agencies have taken a positive approach in stressing the importance of a timely live release.

Although it has been well established that barbless hooks increase the ease of removal (Cooke et al. 2001), this was observed regardless of whether hooks are single or treble (Falk et al. 1974). However, there have been very few studies comparing both barbed versus barbless hooks and single versus treble hooks. Further studies are needed comparing various hook styles to determine the best possible combination for improved survivorship in released fish.

\section{Artificial lures vs. natural bait}

Interestingly, 11 agencies recommended using artificial lures in place of natural bait, but none of these agencies recommended using circle hooks. As mentioned above, circle hooks are generally better suited for use with natural bait (Cooke and Suski 2004). Natural baits are typically ingested more deeply than artificial lures, resulting in longer hook removal times (Siewert and Cave 1990; Cooke et al. 2001). Additionally, hooks that are ingested deeply are more likely to lethally harm organs such as the heart or become lodged in the gut. The Utah Division of Wildlife Resources (2006) addressed this issue by stating that at least 1 of 3 fish caught with bait will die after release, whereas generally 9 of 10 fish caught on flies or lures will survive after release. Although the agency recommended using single barbless hooks, there was no mention of whether anglers should use circle hooks or J-hooks. It is possible that agencies discouraging the use of natural bait 
are then not promoting circle hooks because of the obvious conflict. The OMNR (2006) also promoted the use of artificial lures. The agency specified that if you are using live bait you should set the hook immediately after the strike-an action that must be avoided when using circle hooks (Cooke and Suski 2004). It is recommended that further research be conducted to determine the appropriate bait and hook combination for a given species of fish or body of water.

\section{Scented vs. unscented artificial bait}

Although no agencies mentioned the use of scented artificial baits, evidence suggests that these may be attacked by the fish in a similar manner as live bait, thus increasing mortality (Casselman 2005). Schisler and Bergersen (1996) found that hooking mortality was significantly higher when fish were caught on scented bait than when nonscented artificial bait was used. However, Dunmall et al. (2001) found that there was no effect of scented artificial bait on catch-and-release mortality of smallmouth bass. Because the use of scented artificial bait is increasing, it would be useful for agencies to consider this issue further and provide anglers with guidance on the subject. Additional research is needed before this will be possible.

The Angling Event and Handling

\section{Playing time}

Many agencies placed a great deal of emphasis on the importance of reducing the duration of playing time. Indeed, $84 \%$ of (or 41) agencies recommended bringing the fish in quickly in order to minimize intense struggling. Catch-and-release studies have consistently shown that the duration of the angling event correlates positively with the magnitude of physiological disturbance and time required for recovery (e.g., Gustaveson et al. 1991; Kieffer et al. 1995; Schreer et al. 2001; Thorstad et al. 2003). In fact, Thompson et al. (2002) found that mortality of striped bass increased threefold when angling duration increased from 1 to 3 minutes at $26^{\circ} \mathrm{C}$.

Although most agencies encouraged minimal playing time, few recommended ways of achieving this goal. Studies have shown that the duration of playing time is greatly affected by the choice of equipment. According to Cooke and Suski (2005), anglers should choose optimal equipment matched to the size of fish they are expected to encounter. The OMNR used the following text to emphasize this "... an ultra-light outfit with four pound test line might be fine for $15-25 \mathrm{~cm}$ brook charr, but not for muskellunge. ...Light gear will prolong fight time and greatly reduce the likelihood that the large fish will recover... ." Although $84 \%$ of agencies recommended that anglers minimize playing time, only $16 \%$ of agencies emphasized the importance of an appropriate rod, reel, and line. It is recommended that agencies inform anglers of the intrinsic connection between gear, playing time, and survival. The agencies in Alaska, Florida, and Ontario (among others) serve as positive examples.

It is impossible to ignore the fact that extended fighting is glamorized by the angling media and sought after by many anglers. The challenge lies in shifting the mindset of generations of anglers toward a more sustainable approach to fishing. The angling media (e.g., fishing television shows) could catalyze this shift by spreading the message about the importance of reducing playing times.

\section{Raising fish slowly from depth}

The procedure for releasing fish caught from deep water was addressed by 6 of 49 agencies. Of importance, there was contrasting advice on fishing at depth presented by these agencies. The South Dakota Division of Wildlife (SDDW) recommended raising fish quickly from depths of more than $10 \mathrm{~m}$, whereas the OMNR recommended raising fish slowly from these depths. These two agencies differed in their opinion of the time it takes for a fish to adjust to changes in pressure. The OMNR stated that, "if brought to the surface slowly, fish such as northern pike and walleye can adjust to the change in pressure". The SDDW Web site stated that, "contrary to popular belief, slowly reeling in a fish from deep water does not give it enough time to compensate for the change in pressure." According to the SDDW, fish may require between 20 and 30 minutes to adjust to pressure differences, and that prolonging the time it takes to land and release the fish increases its stress level. The SDDW also stated that the tissues around the gas bladder are often capable of preventing it from increasing in size for up to 5 minutes after the pressure outside of the fish decreases. According to this theory, a fish hooked in deep water should be reeled in quickly and also released as quickly as possible to maximize its chance of survival (SDDW). There were four additional agencies that took the same position as the OMNR on this subject; Alabama, Saskatchewan, Texas, and Utah all recommended raising the fish slowly from depth. Noting that South Dakota and Utah are within a 1-day drive of one another, it is important that these states be consistent in the information they disseminate to anglers. 
Several studies have examined the impact of decompression in fish (Gotshall 1964; Feathers and Knable 1983; Lee 1992; Keniry et al. 1996; Shasteen and Sheehan 1997). Most of these have focused on initial or delayed mortality after decompression in largemouth bass (Micropterus salmoides). Morrissey et al. (2005) argued that there is a need to study decompression in smallmouth bass (Micropterus dolomieu) because these experience greater mortality at live-release angling tournaments than do largemouth bass. One possible explanation is that smallmouth bass typically inhabit deeper habitats than do largemouth bass (Morrissey et al. 2005). Therefore, Morrissey et al. (2005) examined the incidence of external signs of decompression in smallmouth bass after liverelease angling at various depths, as well as the physiological changes associated with decompression. Their findings showed that decompression is not a problem in relatively shallow areas. However, in deep water $(>5 \mathrm{~m})$ there was a significant increase in the incidence of swim bladder overinflation (Morrissey et al. 2005). Internal physiological changes (e.g., tissue damage resulting from increased plasma lactate) also increased significantly at greater depths (Morissey et al. 2005). Although further research is required to determine the optimal way to angle a fish from depth, the study by Morissey et al. (2005) highlighted the sensitivity of smallmouth bass to live-release angling tournaments in deep water-bodies and cast doubt on activities promoted by some natural resource agencies.

\section{Managing a distended air bladder}

Although only five agencies addressed the issue of whether to vent trapped gases in a fish caught from depth, their recommendations were inconsistent and therefore worthy of discussion. The Alabama Department of Conservation and Natural Resources (Alabama DCNR) and the Texas Department of Parks and Wildlife (Texas DPW) provided different instructions for puncturing a distended air bladder. The Alabama DCNR recommended (with illustrations) inserting a large hypodermic needle at a 45-degree angle, under a scale near the tip of the pectoral fin, and gently squeezing the fish. The Texas DPW provided similar instructions, although recommended using a knife blade, wire, or ice pick to puncture the bladder. In addition, the Texas DPW suggested letting the air escape without pressing on the fish. It should be noted that Alabama is the only agency to provide detailed illustrations on the process.
Interestingly, the agencies for Maine, South Dakota, and Utah all recommended against puncturing a distended bladder. According to the Utah Division of Wildlife Resources, fish caught from depths of more than $10 \mathrm{~m}$ cannot be released with any assurance that they will survive, and puncturing the swim bladder with a needle does not improve survival. Similarly, the South Dakota Department of Game Fish and Parks stated that fish often die of this process, either from damage to internal organs or because of the stress involved in being caught and handled. The Maine Department of Inland Fisheries and Wildlife recommended a less intrusive version of the technique for lake trout, instructing anglers to "gently press their thumb along the stomach near the paired belly fins and move it forward a few times to remove air from the bladder". This technique is suitable for lake trout; however, it is not relevant for species that do not have a duct within their swim bladders to release excess gas (i.e., physoclistous species).

The inconsistency among agencies was also reflected in the scientific literature regarding venting swim bladders. Keniry et al. (1996), Collins et al. (1999), and Kerr (2001) recommended venting the swim bladder with a needle to release the gas and enable the fish to swim back to depth. However, St. John and Syers (2005) found that venting failed to reduce mortality. This research topic requires more work before definitive answers can be provided to anglers. At this point, it is recommended that agencies discourage anglers from fishing in deep waters.

\section{Landing nets}

Three agencies stated that anglers should not use landing nets at all. Another 16 agencies promoted the use of nonabrasive landing net alternatives. Recommendations included coated or rubberized mesh, small mesh cotton, and (most commonly recommended) soft knotless nylon or rubber. These recommendations are consistent with a recent study (Barthel et al. 2003) involving freshwater fish that found that the degree of injury (including dermal disturbance and fin fraying) varied with the type of landing net mesh, with knotless nylon and rubber being the least injurious and knotted, large, coarse mesh being the most damaging. However, it was also determined that fish landed by hand sustain less physical injury and risk of mortality compared with those landed with a net (Barthel et al. 2003). Although landing fish by hand may be the best option, the reality is that many anglers will never completely abandon the use of landing nets. Rather than discourage the use of 
nets altogether, it is recommended that agencies promote less injurious versions. Interestingly, the majority of agencies $(62 \%)$ did not mention landing nets in their on-line catch-and-release guidelines. These agencies should consider investigating this issue further in order to give anglers the knowledge and opportunity to choose safe alternatives to conventional landing nets.

\section{Proper handling techniques}

Injuries associated with slime removal are often the result of poor handling techniques, namely, handling the fish with dry hands. Of the 25 agencies $(51 \%)$ that discuss the importance of slime or scales, 19 also recommend handling a fish with wet hands, wet gloves, or a version thereof. Specifically, 59\% recommend wet hands, $16 \%$ recommend wet gloves, and $25 \%$ recommend either. As an example, the Oklahoma Department of Wildlife Conservation recommended that anglers avoid holding fish with dry hands to prevent removal of the protective slime coating. Similarly, the OMNR stresses that the slime coating helps protect a fish from disease. There are not any specific experiments that deal with slime removal or handling in a catch-and-release context. However, in aquaculture facilities it is well known that fish should be handled with wet hands and as minimally as possible.

There was a lack of consistency within and among agencies with regard to how fish should be held. Although the majority (59\%) of agencies instructed anglers to avoid contact with gills, some recommended holding the fish by its gill covers. For example, the Montana Department of Fish and Wildlife and Parks warned anglers not to touch the gills or eye sockets; however, they recommended holding toothy fish by grasping them across the gill covers (opercula). The OMNR also advised against holding fish by the gills or eyes; however, they stated that "most species of fish can be held by placing your wetted hand firmly over the top of the head and gill covers." Arguably, because of the proximity of these two structures, inexperienced anglers are likely to misinterpret this information and damage the thin-walled gills.

Instructions for proper handling were generally confusing because some agencies made size and species distinctions and others did not. Few agencies (27\%) recommended special handling techniques for larger fish, namely, holding the fish horizontally with support from a hand placed on the ventral surface. The Kentucky Department of Fish and Wildlife Resources simply recommended holding salmonids upside down and black bass (Micropterus spp) by the lower jaw.
According to the Tennessee Wildlife Resources Agency, fish should be landed with a lip hold and held vertically. The Montana agency also recommended grasping largemouth bass by the lower jaw, smaller fishes with a hand around the midsection, and fish with teeth by grasping them across the gill covers.

There were no agencies that discussed the problems associated with holding large fish vertically. Because fish do not experience gravitational forces under water, being held against gravity has the potential to seriously damage internal organs. At present, there are no scientific studies associated with handling and orientation of large fish. Therefore, it is recommended that research be conducted on this topic. In addition, when describing handling techniques, agencies should consider using illustrations to demonstrate correct techniques. Interestingly, none of the agencies recommended using commercially available gripping devices (e.g., Boca Grip ${ }^{\mathrm{TM}}$ ) for restraining fish.

\section{Air exposure}

Air exposure was the most widely discussed catch-andrelease issue among agencies. It was found that 44 of 49 agencies provided advice on the subject. The most common recommendation (64\%) was to keep the fish in the water at all times. This is consistent with studies showing that air exposure is extremely harmful in fish that have experienced physiological disturbances associated with angling (Ferguson and Tufts 1992; Cooke et al. 2001; Suski et al. 2004). Ferguson and Tufts (1992) found that when rainbow trout were exposed to air for either 30 or 60 seconds after exhaustive exercise, mortality increased from $38 \%$ to $72 \%$, respectively. While these results strongly support the notion that a fish should be kept in the water at all times, the reality is that holding fish for photographs is a habitual and significant part of the experience for many anglers. Air exposure also tends to occur when anglers remove hooks, and weigh and measure fish. Perhaps it is more relevant for agencies to encourage anglers to have tools and equipment (i.e., measuring board, camera) ready so as to minimize air exposure. Several agencies have already taken this approach (e.g., Alberta and British Columbia). The Arkansas Fishing Guidebook (Arkansas Game and Fish Commission 2005) recommends that anglers take a photograph with fish gently on the surface of the water. Other recommendations relating to maximum air exposure include "as little as possible" (25\%), "no longer than you can hold your breath" (1\%), and finally, the Maine Department of Inland Fisheries and 
Wildlife (2006) has set a limit of 15 seconds. It is important to note that Maine is the only agency to set an exact time limit for air exposure. Recommendations such as these that vary from one agency to the next do not necessarily promote best practice. We need to move toward developing a common threshold that anglers can trust and put in practice (Schreer et al. 2005).

\section{Calming fish}

Because there is such a strong correlation between stress and mortality, strategies for minimizing stress during catch-and-release should be encouraged. Eight $(16 \%)$ agencies recommend ways for anglers to calm fish prior to release. However, this assumes that the fish has been removed from the water, an action that most agencies discourage. For example, the agencies for Alabama and Texas recommend turning the fish on its back or covering its eyes with a wet towel. They also state that fish should be kept in the water at all times. The calming techniques are therefore presented as a last resort. It is recommended that agencies stress the importance of minimizing air exposure, but also offer calming techniques in the case the fish must be brought onboard for hook removal.

\section{Temperature}

Although consistently addressed in the scientific literature, temperature was not widely discussed among agencies. Nine of 49 agencies warned of the problems associated with extreme water temperatures. Of these, seven agencies discussed warm water temperatures, and two discussed cold water temperatures. South Dakota was the only agency to address both extremes. Considering that water temperature is regarded as the "master factor" in the biology of fishes, it is surprising that angling at extreme temperatures was not incorporated into all agency guidelines (Brett 1971).

Issues associated with warm water were also more extensively covered in the literature than those associated with cold water temperatures. According to Cooke and Suski (2005), angling at high water temperatures is correlated with increased physiological disturbances and the probability of death. For example, mortality among Atlantic salmon is minimal when angled at water temperatures between $\sim 8^{\circ} \mathrm{C}$ and $18^{\circ} \mathrm{C}$, but as water temperatures increase to greater than $18^{\circ} \mathrm{C}$, the risk of angling-induced mortality increases considerably (e.g., Thorstad et al. 2003). As for cold temperatures, there is evidence that fish exposed to freezing air for any length of time can suffer from frozen eyes and gills (Ontario and Vermont). Despite evidence that angling in extreme water temperatures increases mortality, $83 \%$ of agencies did not address this issue in their catch-and-release guidelines. Given the fact that many angling tournaments occur during the summer months and ice fishing is increasingly popular, there should be more emphasis on avoiding angling during extreme temperatures or at least adjusting angler behavior to minimize stress. Adjusting behaviors may involve taking extra precautions to avoid any air exposure.

\section{Dehooking and Release}

\section{Cutting line if deeply hooked}

The majority ( $90 \%$ or 44 ) of agencies recommended cutting the line when a fish is deeply hooked. This is consistent with numerous studies showing that leaving hooks embedded increases survival of deeply hooked fish (Schill 1996; Schisler and Bergersen 1996; Taylor et al. 2001). In contrast, removing hooks often results in mortality associated with increased handling time and air exposure (Hulbert and Engstrom-Heg 1980; Jordan and Woodward 1994). It is important to note, however, that the aforementioned findings are limited because the studies were not specifically designed to examine mortality associated with hook removal. Consequently, the studies suffer from small sample sizes and little power. Two recent studies (Tsuboi et al. 2006; Wilde and Sawynok unpublished) were explicitly designed to identify means of increasing survivorship in deeply hooked fish. Wilde and Sawynok (unpublished) examined capture and recapture records $(n=248,010)$ for 27 species of Australian fish. Results across all species and habitats suggest that survival was $18 \%$ greater, on average, among fish in which hooks were not removed. Based on these findings, Wilde and Sawynok (unpublished) concluded that there was no clear benefit to removing hooks from deeply hooked fish. Tsuboi et al. (2006) cut the line and left the hook embedded in 77 deeply hooked white-spotted char during a 10-week period. Of these, $93.5 \%$ were recaptured, and in many cases the hooks were corroded or had been evacuated (Tsuboi et al. 2006). These findings support the notion that cutting the line is a safe alternative to removing the hook in deeply hooked fish.

Although the majority of agencies recommended cutting the line, some advised the opposite. The 2006 Nebraska Fishing Guide states that deeply embedded hooks should be removed using a hemostat or hookremoval tool if at all possible. According to the $\mathrm{Ne}$ braska Game and Parks Commission, "this is presently 
considered the best method to increase chances of survival for deeply hooked fish." Similarly, the West Virginia Division of Natural Resources stated that deep hooks should be removed carefully and the line should be cut only when attempts at removing the hook fail. These agencies should revisit their guidelines in light of recent developments within the scientific community.

\section{Instruments and techniques for hook removal}

Although $86 \%$ of agencies recommended cutting the line when it is deeply hooked, far fewer (24\%) provided instructions on how to remove a hook from a fish in a normal situation. This is significant because prolonged hook removal is directly correlated with excessive handling and air exposure (Cooke et al. 2001). Air exposure is one of the most stressful components of the entire catch-and-release angling experience for a variety of different taxa (see above). Survival of fish from which anglers do remove hooks can be increased by educating anglers in best practices. Meka (2004) noted that training was required to promote proper hook removal techniques to minimize injury and that even barbless hooks can injure fish if not properly removed. Although few agencies provide instructions on hook removal, $69 \%$ recommend using specific tools. Of these, $34 \%$ recommend pliers and $66 \%$ recommend a combination of hemostats, fingers, pliers, forceps, hookouts, dehookers, and hook disgorgers. It is recommended that agencies not only list appropriate tools but also provide anglers with detailed instructions on hook removal. Illustrated guidelines such as those provided by the Delaware Division of Fish and Wildlife are an excellent means of disseminating this information to anglers.

\section{Resuscitation of exhausted fish}

The procedure for resuscitating (or reviving) an exhausted fish is described by 35 (or $71 \%$ ) agencies. Of these, most $(63 \%)$ recommended moving the fish "back and forth" in the water, 14\% holding the fish facing upstream, $11 \%$ moving the fish slowly forward, $3 \%$ moving the fish in an S-shaped pattern, and 3\% moving the fish side to side. Six percent present a combination of the above alternatives. The level of inconsistency among agencies is of concern because it incites confusion in anglers and perpetuates poor practice. In order to determine which of these approaches is most effective, one must consider the biology of a fish. For a fish to efficiently transfer oxy- gen from water to its blood, water must pass over the gills from front to back (i.e., enter the mouth and exit via the opercula). This is because water must flow in the opposite direction from blood to produce a gradient that drives oxygen transfer (Gilmour 1997). Thus, resuscitating fish in a back-and-forth manner is not ideal because having the fish move backwards through the water does not optimize oxygen uptake. Because most sportfish can be easily gripped by the lower jaw, the most sensible approach for resuscitation is to move fish in an S-shaped (or figure "eight") pattern. At the time of this study, the Saskatchewan Fish and Wildlife Department was the only agency recommending this technique. Agencies recommending more than one option for resuscitation add to the confusion. For example, the Alaska Department of Fish and Game recommended pointing your catch into a slow current, or gently move it back and forth in the water. It is recommended that agencies re-examine their guidelines in the context of fish biology and select the single most effective resuscitation method. The correct resuscitation procedure should be described in detail and should be based on relevant scientific information. Anglers would benefit from creative visual aids depicting the mechanisms for oxygen uptake within a fish. In addition, it would be useful for agencies to provide an estimate of the length of time it generally takes to revive a fish. At present, there are few studies explicitly on this topic providing much opportunity for research.

\section{Keeping injured fish where legal}

Eight (16\%) agencies recommended that anglers keep dead or severely injured fish that are of legal size and in-season. This is based on the premise that injured fish (i.e., deeply hooked, hooked around the gills, or bleeding profusely) have a much lower chance of survival once released and should therefore be retained as part of one's "limit." The same rationale applies for dead fish. Anglers who abide by this rule are taking responsibility for their impact on each individual fish. From an ethical position, this is a highly respectable code of conduct that encourages best practice. Of course, where a fish cannot be retained legally, its chances for survival can be improved by cutting the line and releasing it with the hook left in. It is recommended that the remaining $84 \%$ agencies look to agencies such as British Columbia, Manitoba, Saskatchewan, and Yukon, among others, for positive examples related to keeping injured fish where legal. 


\section{Predators}

Although the added risk of released fish being preyed upon was not discussed by any agencies, a recent study found a correlation between predator density and survivorship of released fish. Cooke and Philipp (2004) found that in areas where shark abundances were high, $39 \%$ of bonefish (Albula spp.) were consumed by sharks within 30 minutes of release. In low shark abundance areas, all released bonefish survived (Cooke and Philipp 2004). Cooke and Philipp (2004) suggested several ways of avoiding unnecessary mortality from predators. Of primary importance is angling and releasing fish quickly. Released fish are particularly vulnerable to predation if they have been exhaustively angled and exposed to air, leading to loss of equilibrium (Cooke and Philipp 2004). Secondly, anglers should avoid releasing fish in the immediate area when the predation threat is high (Cooke and Philipp 2004). Alternative options include relocation or keeping fish in a live well until they are less stressed. It is recommended that agencies inform anglers of this additional threat to released fish. Specifically, anglers should be reminded of the fundamental importance of minimizing playing time, handling, and air exposure during catch-and-release.

\section{Recommendations and Conclusions}

This review of catch-and-release angling guidelines revealed immense variation in the breadth and depth of material presented. However, of more concern is the observation that some agencies actually recommend handling practices that could harm fish. For example, moving fish back and forth in an effort to resuscitate them may actually lead to delayed cardiorespiratory recovery. In addition, contemporary research suggests that fish hooks should be left in by cutting the line; however, several agencies suggest that hooks should always be removed. This was not the first study to find incorrect scientific information on Internet Web sites. Alarmingly, on-line medical sources have also been identified as containing substantial errors (Impicciatore et al. 1997; McLeod 1998). In fact, several authors have urged the need to assess all public-oriented healthcare information on the Internet for accuracy, completeness, and consistency (Impicciatore et al. 1997; McLeod 1998).

There is also substantial contradiction among agency Web sites, making it difficult for anglers to decide which agency's advice is the best. At the very least, this synthesis will hopefully draw attention to the need to have consistent guidelines from one agency to the next. Inconsistent or vague information is less likely to be taken seriously by anglers and therefore does not help promote effective catch-and-release techniques. There is also a need to have clearer catch-and-release angling guidelines. For example, there is a need to move toward developing thresholds for air exposure that anglers can understand and put in practice. Furthermore, rather than simply promoting zero air exposure, agencies should take a more practical approach and recommend having tools and equipment (i.e., camera) ready so as to minimize air exposure.

Whenever possible, simplified guidelines should be supplemented with detailed scientific accounts with supporting citations. For specialized fisheries (e.g., muskellunge) or issues (e.g., tournaments, circle hooks), it may be informative to have more detailed and specific guidelines that are linked from the generalized guidelines. For example, unlike most agencies, OMNR actually has a more technical document that is available in addition to their simplified online guidelines. This document (Catch-and-release angling: $A$ review with guidelines for proper fish handling practices; Casselman 2005-OMNR) is available via a separate link called "publications." It is recommended that there be a link from the general guidelines to the more comprehensive document so that anglers can easily find background information and justification for various recommendations. Even the most general catch-and-release guidelines should be easily accessible to anglers and thus should be available through a link on the primary fisheries Web sites of natural resource agencies.

Agencies face a difficult task in trying to develop generic guidelines for catch-and-release when there is clearly substantial interspecific variation as well as differences in fishing techniques. Perhaps a single American Fisheries Society taskforce dedicated to developing generic catch-and-release guidelines would be most effective. Members of the taskforce would not have to be anglers (although some should be); they would simply need to be provided with enough time and money to research the most recent advances in catch-and-release science and to interact with anglers. Their task would involve moving beyond early catchand-release literature (e.g., Muoneke and Childress 1994) that is often regarded as the sole source of information on the subject. In recent months, there have been groundbreaking new discoveries that put in question the effectiveness of conventional catch-andrelease techniques. Several syntheses (e.g., Bartholomew and Bohnsack 2005; Cooke and Sneddon in press) are in publication that will ease the task of reconciling conflicting literature accounts. 
This research project can be used to identify clear deficiencies in knowledge where there is an immediate need for more research. For example, several key topics where there were research deficiencies include the use of fizzing, angling at cold temperatures, and resuscitation techniques. When new information arises from the scientific community, catch-and-release guidelines should be revised in a timely manner and the rationale for the new guidelines provided in order to encourage the angling community to adopt "best practice."

An important assumption in this paper is that anglers obtain their information on catch-and-release from government sources rather than peers, trial and error, or the outdoor media. In reality, most anglers likely learn from a combination of these sources. However, government sources likely serve as the conduit of information between the scientific literature and the public. As such, we believe that natural resource agencies are the appropriate target of initial attempts to ensure that catch-and-release guidelines are consistent with the best scientific information. That said, additional research examining how anglers obtain their information on catch-and-release would be ex- tremely valuable to identify the best measures for disseminating information to the angling public. Another assumption is that anglers do indeed follow government guidelines. Anglers are intimately connected to the resource and in many cases may have insight into catch-and-release issues that, although not based on science, are based on years of experience. In fact, anglers may be able to identify guidelines that are deleterious to fish and decide to ignore them. Hence the need for agencies to ensure that information disseminated to anglers is correct in an effort to maintain scientific credibility.

Agencies or an appropriate taskforce need to adopt a more formal approach to disseminating catch-andrelease research to the public. Table 2 provides adapted recommendations from a recent Ocean Studies Board document ("Improving the Use of the 'Best Scientific Information Available' Standard in Fisheries Management"; Ocean Studies Board 2004), such that they apply directly to catch-and-release guidelines. When considered together, the six recommendations work to ensure that only the best scientific information available reaches the public. When producing "paper" materials for distribution, there may be more peer

Table 2 Recommendations for disseminating catch-and-release guidelines to the public as adapted from a recent Ocean Studies Board document (Improving the Use of the "Best Scientific Information Available" Standard in Fisheries Management; 2004)

\begin{tabular}{|c|c|}
\hline Recommendation & Application to catch-and-release guidelines \\
\hline Relevance & $\begin{array}{l}\text { Catch-and-release guidelines should be representative and relevant to the fish and fisheries in a given } \\
\text { jurisdiction. Species-specific data are not essential for catch-and-release, but they may be needed for some } \\
\text { specialized fisheries (Cooke and Suski 2005). It is possible to use catch-and-release information from other } \\
\text { species (ideally with similar life-history) and in many instances, this will represent the best available } \\
\text { scientific information. }\end{array}$ \\
\hline Inclusiveness & $\begin{array}{l}\text { Catch-and-release guidelines should be based on scientific advice obtained from relevant disciplines including } \\
\text { physiology, fisheries management, and outreach. The team assembled to develop agency catch-and-release } \\
\text { guidelines should provide a range of opinions and be able to assess alternative points of view. When } \\
\text { provided with anecdotal information, it should be carefully evaluated prior to incorporating it into } \\
\text { guidelines. In some cases, anecdotal information may be the best information available. This needs to be } \\
\text { clearly noted and efforts should be made to replace the anecdotal information with scientific data. This } \\
\text { means identifying knowledge gaps and committing research efforts to remedy the deficiency. }\end{array}$ \\
\hline Objectivity & Data used to support catch-and-release guidelines should be unbiased and obtained from credible sources. \\
\hline $\begin{array}{l}\text { Transparency and } \\
\text { openness }\end{array}$ & $\begin{array}{l}\text { Beyond simply providing guidelines, it is important to provide the rationale for the choice of the information } \\
\text { that is to be disseminated to the public. This should include providing a more scientific account with } \\
\text { justification and references and should be available to the public. When catch-and-release guidelines have } \\
\text { limitations, they should be noted. }\end{array}$ \\
\hline Timeliness & $\begin{array}{l}\text { Data need to be carefully analyzed prior to formalizing them as catch-and-release guidelines. When new data } \\
\text { are applicable, guidelines should be refined in a timely manner. It is also possible that new information will } \\
\text { arise and be incorporated into catch-and-release guidelines prior to the data being formally published in } \\
\text { peer-reviewed outlets. When this is done, it is important to acknowledge this limitation. }\end{array}$ \\
\hline Peer review & $\begin{array}{l}\text { Peer review is the most standard means of assessing the quality of scientific information including catch-and- } \\
\text { release research. Including the angling public in this process is also beneficial to ensure relevancy. It is } \\
\text { important to acknowledge that peer review is not infallible. In the cases of state and provincial agencies, } \\
\text { internal peer review capacity for catch-and-release guidelines may be sufficient if they are fully exercised. } \\
\text { However, the current study reveals that external review of catch-and-release guidelines may be required to } \\
\text { ensure that the guidelines are indeed based in the best available science. This is particularly relevant when } \\
\text { the information exceeds the expertise of the agency, when there is scientific uncertainty, or when the } \\
\text { findings are controversial. }\end{array}$ \\
\hline
\end{tabular}


review and evaluation prior to publishing because of the generally slow publication process. Conversely, Internet material can be rapidly assembled and may be published quickly without proper assessment. Because the public is increasingly looking toward electronic sources for scientific information, it is essential that government natural resource agencies provide timely information that is accessible and credible (Whitson and Davis 2001). Recreational fisheries science, resource management, fish populations, and individual fish will be best served if the catch-and-release information disseminated through natural resource agency Web sites is consistent with best available scientific information and is regularly updated to reflect contemporary knowledge.

Acknowledgments We thank Fred Michel, Ildi Munro, the Institute of Environmental Science at Carleton University, and the Fish Ecology and Conservation Physiology Laboratory at Carleton University. Robert Arlinghaus and James Bohnsack kindly provided comments on an earlier version of the manuscript. This research was supported by funds from Carleton University, the Charles A. and Anne Morrow Lindberg Foundation, the Canadian Foundation for Innovation, the Rainy Lake Fisheries Trust, and the Natural Sciences and Engineering Research Council.

\section{References}

Arkansas Game and Fish Commission (2005) The Arkansas fishing guidebook. Arkansas Game and Fish Commission, Little Rock, Arkansas

Arlinghaus R, Mehner T, Cowx IG (2002) Reconciling traditional inland fisheries management and sustainability in industrialized countries, with emphasis on Europe. Fish Fisheries 3:261-316

Barthel BL, Cooke SJ, Suski CD, Philipp DP (2003) Effects of landing net mesh type on injury and mortality in a freshwater recreational fishery. Fisheries Res 63:275-282

Bartholomew A, Bohnsack JA (2005) A review of catch-andrelease angling mortality with implications for no-take reserves. Rev Fish Biol Fisheries 15:129-154

Brett JR (1971) Energetic responses of salmon to temperature. A study of some thermal relations in the physiology and freshwater ecology of sockeye salmon (Oncorhynchus nerka). Am Zoologist 11:99-113

Casselman SJ (2005) Catch-and-release angling: A review with guidelines for proper fish handling practices. Fish and Wildlife Branch, Ontario Ministry of Natural Resources, Peterborough, Ontario

Collins MR, McGovern JC, Sedberry GR, Meister HS, Pardieck $\mathrm{R}$ (1999) Swim bladder deflation in black sea bass and vermilion snapper: Potential for increasing postrelease survival. North Am J Fisheries Manage 19:828-832

Cooke SJ, Cowx IG (2004) The role of recreational fisheries in global fish crises. BioScience 54:857-859

Cooke SJ, Cowx IG (2006) Contrasting recreational and commercial fishing: Searching for common issues to promote unified conservation of fisheries resources and aquatic environments. Biol Conserv 128:93-108
Cooke SJ, Sneddon LU (in press) Animal welfare perspectives on recreational angling. Appl Animal Behav Sci

Cooke SJ, Suski CD (2005) Do we need species-specific guidelines for catch-and-release recreational angling to conserve diverse fishery resources? Biodivers Conserv 14:1195-1209

Cooke SJ, Suski CD (2004) Are circle hooks an effective tool for conserving marine and freshwater recreational catch-andrelease fisheries? Aquat Conserv Marine Freshwater Ecosystems 14:299-326

Cooke SJ, Philipp DP (2004) Behavior and mortality of caughtand-released bonefish (Albula spp.) in Bahamian waters with implications for a sustainable recreational fishery. Biol Conserv 118:599-607

Cooke SJ, Philipp DP, Dunmall KM, Schreer JF (2001) The influence of terminal tackle on injury, handling time, and cardiac disturbance of rock bass. North Am J Fisheries Manage 21:333-342

Cooke SJ, Schreer JF, Dunmall KM, Philipp DP (2002) Strategies for quantifying sublethal effects of marine catch-andrelease angling: insights from novel freshwater applications. Am Fisheries Soc Symp 30:121-134

Cooke SJ, Suski CD, Barthel BL, Ostrand KG, Tufts BL, Philipp DP (2003) Injury and mortality induced by four hook types on bluegill and pumpkinseed. North Am J Fisheries Manage 23:883-893

Cowx IG (2002) Recreational fisheries. In: Hart PBJ, Reynolds JD (eds), Handbook of fish biology and fisheries, volume II. Blackwell Science, Oxford, pp 367-390

Diggles BK, Ernst I (1997) Hooking mortality of two species of shallow-water reef fish caught by recreational angling methods. Marine Freshwater Res 48:479-483

DuBois RB, Margenau TL, Stewart RS, Cunningham PK, Rasmussen PW (1994) Hooking mortality of Northern Pike angled through ice. North Am J Fisheries Manage 14:769775

Dunmall KM, Cooke SJ, Schreer JF, McKinley RS (2001) The effect of scented lures on the hooking injury and mortality of smallmouth bass caught by novice and experienced anglers. North Am J Fisheries Manage 21:242-248

Falk MR, Gillman DV, Dahlke LW (1974) Comparison of mortality between barbed and barbless hooked lake trout. Technical report series CEN=T-74-1. Canada Department of Environmental Fisheries and Marine Service, Winnipeg, Manitoba, Canada

Feathers MG, Knable AE (1983) Effects of depressurization upon largemouth bass. North Am J Fisheries Manage 3:8690

Ferguson RA, Tufts BL (1992) Physiological effects of brief air exposure in exhaustively exercised rainbow trout $(\mathrm{On}$ corhynchus mykiss): implications for 'catch and release' fisheries. Can J Fisheries Aquat Sci 49:1157-1162

Gilmour KM (1997) Gas exchange. In: Evans DH (ed), The physiology of fishes, 2nd ed. CRC Press, Boca Raton, Florida, pp 101-127

Gjernes T, Kronlund AR, Mulligan TJ (1993) Mortality of Chinook and coho salmon in their first year of ocean life following catch and release by anglers. North Am J Fisheries Manage 13:524-539

Gotshall DW (1964) Increasing tagged rockfish (genus Sebastodes) survival by deflating the swim bladder. Calif Fish Game 50:253-260

Gustaveson AW, Wydoski RS, Wedemeyer GA (1991) Physiological response of largemouth bass to angling stress. Trans Am Fisheries Soc 120:629-636 
Hulbert PJ, Engstrom-Heg R (1980) Hooking mortality of worm-caught hatchery Brown Trout. NY Fish Game J 27:1-10

Impicciatore P, Pandolfini C, Gasella N, Bonati M (1997) Reliability of health information for the public on the world wide web: systematic survey of advice on managing fever in children at home. Br Med J 314:1875-1878

Johannes RE (1981) Words of the lagoon: Fishing and marine lore in the Palau District of Micronesia. University of California Press, Los Angeles, California

Jordan SR, Woodward AG (1994) Survival of hook-caught red drum. Proc Ann Conf Southeast Assoc Fish Wildlife Agencies 46:337-344

Keniry MJ, Brofka WA, Horns WH, Marsden JE (1996) Effects of decompression and puncturing the gas bladder on survival of tagged yellow perch. North Am J Fisheries Manage 16:201-206

Kerr SJ (2001) A review of "fizzing"-A technique for swim bladder deflation. Ontario Ministry of Natural Resources, Peterborough, Ontario

Kieffer JD, Kubacki MR, Phelan FJS, Philipp DP, Tufts BL (1995) Effects of catch-and-release angling on nesting male smallmouth bass. Trans Am Fisheries Soc 124:70-76

Lee DP (1992) Gas bladder deflation of depressurized largemouth bass. North Am J Fisheries Manage 12:662-664

Massachusetts Division of Marine Fisheries (2005) Saltwater recreational fishing guide. Division of Marine Fisheries, New Bedford, Massachusetts

McLeod SD (1998) The quality of medical information on the Internet: A new public health concern. Arch Ophthalmol 116:1663-1665

Meka JM (2004) The influence of hook type, angler experience, and fish size on injury rates and the duration of capture in an Alaskan catch-and-release rainbow trout fishery. North Am J Fisheries Manage 24:1309-1321

Morrissey MB, Suski CD, Esseltine KR, Tufts BL (2005) Incidence and physiological consequences of impacts of decompression in smallmouth bass after live-release angling tournaments. Trans Am Fisheries Soc 134:1038-1047

Muoneke MI, Childress WM (1994) Hooking mortality: a review for recreational fisheries. Rev Fisheries Sci 2:123-156

NOAA Fisheries, National Oceanic and Atmospheric Administration (2001) Fisheries of the United States 2000. Silver Spring, Maryland

Ocean Studies Board (2004) Improving the use of the "best scientific information available" standard in fisheries management. National Research Council. The National Academies Press, Washington, D.C

Prince ED, Ortiz M, Venizelos A (2002) A comparison of circle hook and ' $\mathrm{J}$ ' hook performance in recreational catch-andrelease fisheries for billfish. Am Fisheries Soc Symp 30:6679

Quinn S (1996) Trends in regulatory and voluntary catch-andrelease fishing. Am Fisheries Soc Symp 16:152-162

Schaeffer JS, Hoffman EM (2002) Performance of barbed and barbless hooks in a marine recreational fishery. North Am J Fisheries Manage 22:229-235

Schill DJ, (1996) Hooking mortality of bait-caught rainbow trout in an Idaho trout stream and a hatchery: Implications for special-regulation management. North Am J Fisheries Manage 16:348-356

Schill DJ, Scarpella RL (1997) Barbed hook restrictions in catchand-release trout fisheries: A social issue. North Am J Fisheries Manage 17:873-881
Schisler GJ, Bergersen EP (1996) Postrelease hooking mortality of rainbow trout caught on scented artificial baits. North Am J Fisheries Manage 16:570-578

Schreer JF, Cooke SJ, McKinley RS (2001) Cardiac response to variable forced exercise at different temperatures-an angling simulation for smallmouth bass. Trans Am Fisheries Soc 130:783-795

Schreer JF, Resch D, Gately M, Cooke SJ (2005) Swimming performance of brook trout following simulated catch-andrelease angling: Looking for air exposure thresholds. North Am J Fisheries Manage 25:1513-1517

Shasteen SP, Sheehan RJ (1997) Laboratory evaluation of artificial swim bladder deflation in largemouth bass: Potential benefits for catch-and-release fisheries. North Am J Fisheries Manage 17:32-37

Siewert HF, Cave JB (1990) Survival of released bluegill, Lepomis macrochirus, caught on artificial flies, worms, and spinner lures. J Freshwater Ecol 5:407-411

St. John J, Syers CJ (2005) Mortality of the demersal West Australian dhufish, Glaucosoma hebraicum (Richardson 1845) following catch and release: The influence of capture depth, venting and hook type. Fisheries Res 76:106-116

Suski CD, Killen SS, Cooke SJ, Kieffer JD, Philipp DP, Tufts BL (2004) Physiological significance of the weigh-in during liverelease angling tournaments for largemouth bass. Trans Am Fisheries Soc 133:1291-1303

Taylor MJ, White KR (1992) A meta-analysis of hooking mortality of nonanadromous trout. North Am J Fisheries Manage 12:760-767

Taylor RG, Wittington JA, Haymans DE (2001) Catch-andrelease mortality rates of Common Snook in Florida. North Am J Fisheries Manage 21:70-75

Thompson JA, Hughes SG, May EB, Harrell RM (2002) Effects of catch and release on physiological responses and acute mortality of striped bass. Am Fisheries Soc Symp 30:139 143

Thorstad EB, Næsje TF, Fiske P, Finstad B (2003) Effects of hook and release on Atlantic salmon in the River Alta, northern Norway. Fisheries Res 60:293-307

Tsuboi J, Morita K, Ikeda H (2006) Fate of deep-hooked whitespotted charr after cutting the line in a catch-andrelease fishery. Fisheries Res 79:226-230

Turek SM, Brett MT (1997) Comment: Trout mortality from baited barbed and barbless hooks (and reply). North Am J Fisheries Manage 17:807

Whitson TL, Davis L (2001) Best practices in electronic government: Comprehensive electronic information dissemination for science and technology. Gov Information Q 18:79-91

Wilde GR, Sawynok W (unpublished manuscript) Effect of hook removal on recapture rates in 27 species of angler-caught fishes in Australia. Texas Tech University

Wilde GR, Muoneke MI, Bettoli PW, Nelson KL, Hysmith BT (2000) Bait and temperature effects on Striped Bass hooking mortality in freshwater. North Am J Fisheries Manage 20:810-815

Wydoski RS (1977) Relation of hooking mortality and sublethal hooking stress to quality fishery management. In: Barnhart RA, Roelofs TD (eds), Catch-and-release fishing as a management tool. Humbolt State University, Arcata, California, pp 43-87 